\title{
Gabriela Borges e Vítor Reia-Baptista (orgs.) (2008), Discursos e Práticas de Qualidade na Televisão, Lisboa, Livros Horizonte, 381 pp.
}

Eduardo Cintra Torres

São frequentíssimos no espaço público textos ou referências a uma "televisão de qualidade". Todavia, raramente ou mesmo nunca são acompanhados de uma explicação, cabal ou meramente indicativa, do que se entende por qualidade. Desta forma, a "qualidade em televisão" não passa muitas vezes de um argumento de autoridade de quem ocupa o espaço público, em geral membros das elites, com os seus próprios critérios de gosto e de classe. Gabriela Borges e Vítor Reia-Baptista, docentes da Universidade do Algarve, lançaram-se na tarefa de reunir um conjunto de reflexões académicas sobre o “conceito de difícil definição" que é a “qualidade” em televisão. Que o tenham feito é já um primeiro conseguimento deste livro. Noutros países, os Estudos Televisivos, enquanto área específica dos Estudos Mediáticos, debruçam-se sobre esta matéria há duas décadas; que este compêndio surja agora é o sinal de que se ultrapassa nesta matéria o proverbial atraso português.

O segundo conseguimento deste livro é colmatar outra falha habitual do mundo editorial e académico português: a ausência de manuais, isto é, livros de leitura, isto é, selectas, isto é, compêndios. Eles estão de tal forma longe do nosso universo que é comum usar-se entre nós a palavra inglesa readers. As selectas, escolha organizada de textos sobre uma determinada matéria, fazem falta ao ensino e aos oficiais do ofício a que respeitam. Os Livros Horizonte publicaram alguns na área dos media e da comunicação, como os organizados por João Pissarra Mendes (Comunicação e Identidades Sociais, 2008, e Comunicação e Sociedade, 2002), mas são necessários mais, para proporcionar aos estudantes e interessados de língua portuguesa selecções de textos em português e de autores portugueses.

Chegamos assim ao terceiro conseguimento desta selecta: traz-nos autores de países que não estão normalmente acessíveis. Sujeitos a uma involuntária hegemonia cultural e académica anglo-americana, os leitores portugueses podem esquecer-se ou ignorar o que se investiga e publica em muitos outros países dos hemisférios norte e sul. Este livro inclui textos de autores portugueses, brasileiros, mexicanos, argentinos, espanhóis, italianos, etc. Os autores consagrados anglo-americanos estão presentes apenas pelas citações nos vários textos.

Este manual está bem organizado e bem apresentado pelos seus autores. Analisam-se os discursos sobre a qualidade, mas num registo bem próximo da prática. Esse modelo está presente logo no primeiro texto, do brasileiro Arlindo Machado, onde ele completa a sua concepção de TV de qualidade com um repertório de programas que considera 
enquadrados nesse modelo. Jorge la Ferla procura igualmente estabelecer um "reportório notável de programas", no caso da TV argentina, enquanto João Freire Filho averigua a evolução do debate sobre a qualidade no Brasil.

Estes textos abrem a primeira parte do livro, dedicada aos discursos sobre a qualidade; depois de um capítulo sobre a regulação, seguem-se dois artigos sobre modelos de programação: do México (Francisco Hernández Lomelí) e do canal público 2: em Portugal (G. Borges). A primeira parte termina com um capítulo sobre as literacias, ou formas de aprendizagem do consumo dos media que permitam aos consumidores dominarem melhor a sua própria leitura e observação dos conteúdos.

Se esta parte do livro acentua a concepção da qualidade associada à de programação ou grelha, a segunda parte aborda as práticas de qualidade associadas a programas, géneros ou linhas de programação concretas. São dez textos - só eles seriam um livro, como os da primeira parte, aliás - com origem em vários países, como EUA, Brasil, Grã-Bretanha e Itália. Os capítulos estão divididos em reflexões sobre programas ficcionais, infantis e jornalísticos. Os textos, resultantes de investigações, dão a conhecer experiências riquíssimas com pouca ou nenhuma divulgação académica no universo anglo-americano e por tabela em Portugal, como as do Brasil, Argentina ou México. A título de exemplo, refira-se o texto de Yvana Fechine, "Núcleo Guel Arraes: uma proposta de qualidade na televisão brasileira", que relata uma fecunda experiência, no âmbito da Rede Globo, de televisão de qualidade com êxito popular continuado, que garante a continuação do seu núcleo criativo e produtor desde há décadas. O chefe deste núcleo assinou inúmeros programas da Rede Globo (sem divulgação em Portugal) e, a partir dos anos 90, tornou-se um dos responsáveis pela reconfiguração do mercado audiovisual brasileiro, através da proposta de articulação das produções televisiva e cinematográfica, como refere a investigadora no livro recente que editou com Alexandre Figuerôa, Guel Arraes: Um inventor no audiovisual brasileiro (Recife, Edições CEPE, 2008), livro no qual está incluído este mesmo texto.

A diversidade de contribuições é enriquecedora, mas por isso mesmo sente-se neste manual a falta de uma síntese teórica sobre a qualidade em televisão. Seria importante disponibilizar à comunidade académica um texto que fornecesse argumentos sintéticos para a questão de partida - "o que é a qualidade em televisão". Como classificar, quanto à qualidade, uma grelha ou um programa? Que critérios concretos seguir e que possam ser usados comparativamente para sucessivos programas ou grelhas? Sem essa síntese, este livro rico de exemplos permite pensar que a classificação sobre a qualidade só é atingível casuisticamente e no âmbito de uma análise carregada de historicismo. Ora, deve ser possível estabelecer-se uma ferramenta de análise com critérios "técnicos" (para usar o paradigma, ainda válido, de Aristóteles na Poética) que exclua pressupostos de classe ou de gosto. Essa ferramenta de análise poderia aplicar-se a todos os casos concretos de programação de TV generalista, de TV temática, de géneros e de programas isolados, seja de estações públicas ou privadas. 